\title{
Survey of Urinary Aflatoxin Levels Among Residents of Makueni County, Kenya: A Follow-Up Study
}

\author{
Martin Buuria, Michael Gicherub, Joshua Mutisoc, Festus Mulakolid \\ Department of zoological science, Kenyatta University Nairobi, Kenya \\ Department of zoological science, Kenyatta University Nairobi, Kenya \\ Department of zoological science, Kenyatta University Nairobi, Kenya \\ Department of zoological science, Kenyatta University Nairobi, Kenya \\ Correspondence to: Martin Buuri (buuri26@gmail.com)
}

\begin{abstract}
Although fungi are known to be less pathogenic and mostly saprophytic in their nature as compared to other groups of microbes, those that produce aflatoxin have been associated with severe human disease. An example of such disease is Aflatoxicosis caused by soil-borne pathogenic fungi of the species Aspergillus parasiticus and Aspergillus flavus. They produce a mycotoxin substance that is carcinogenic to the human liver with severe outcomes. The objective of this study was to determine urinary aflatoxin levels among the residents of Makueni County, previously affected by Aflatoxicosis.

This was a cross-sectional study that involved the use of primary data collected from 106 participants. The method for data collection included a structured questionnaire and the collection of the urine samples for aflatoxin MI analysis at Bora Biotech Laboratories LTD. The urinary levels of AFMI were detected by use of an ELISA kit. Data was entered in SPSS and analysed through Chi-Square for the association.

The study participants, including both male and female, had an age of between 15 and 91 years and with an average age of $41 \pm 18$. Out of the 106 study participants, $n=68(72 \%)$ were females and $n=26(28 \%)$ were males. Majority of the study participants were with a median age of 24 years old. AFM1 levels were detected in $99.1 \% \%$ of all urine samples at a range of $25-2337 \mathrm{pg} . / \mathrm{ml}$. The mean and median concentration of AFMl in urine was $637.6 \pm 512.7 \mathrm{and} 525 \mathrm{pg} . / \mathrm{mL}$, respectively.

The results of this study provide information on the current situation of aflatoxin exposure. From what is evident from our study a lot needs to be done to mitigate on the long-term effect of this high exposure. Therefore, the study encourages the concerned ministry to have a broader focus on the extent of aflatoxin food contamination from this region plus other regions across the country.
\end{abstract}

Keywords: Urinary Aflatoxin Levels in Makueni County, Kenya 


\section{INTRODUCTION}

Fungi are a group of microbes found everywhere in 1 the environment and have been associated with human illness. Although fungi are known to be less pathogenic and mostly saprophytic in nature as compared to other groups of microbes, those that produce aflatoxin have been associated with severe human disease. An example of such disease is Aflatoxicosis caused by soil-borne pathogenic fungi of the species Aspergillus parasiticus and Aspergillus flavus. These two species are known to contaminate foodstuffs such as maize, rice, groundnuts, sorghum, wheat, millet and cassava among others. They produce a mycotoxin substance that is toxic to the human liver with severe outcomes. For those exposed to this carcinogenic Aflatoxin, the condition may range from acute to chronic state. The severity of the condition is related to the host factors, which include; age, diet, nutrition quality, the extent of the exposure, other underlying diseases condition and gender of the affected individual. Clinical manifestation in Aflatoxicosis include; severe jaundice, liver cirrhosis and imminent liver failure. Other organs affected by Aflatoxin Bl (AFBl) apart from the liver include; oesophagus causing oesophagial carcinoma which is the $6^{\text {th }}$ most prevalent type of cancer globally

Historically Aflatoxin discovery was in Great Britain in the 1960s, after an outbreak of a disease in turkeys that was referred to as Turkey $\mathrm{X}$ disease by then. During this outbreak over 100.000 people lost their lives. After investigation, this mortality was discovered to be caused by a fungal metabolite called Aflatoxin common in mouldy cereal feeds. ${ }^{[1-3]}$ This was followed by numerous outbreaks that were reported globally. Aflatoxins are poisonous molecules produced by certain kinds of fungi (mould) that are found naturally all over the world. They can contaminate food cereals and present a harmful effect on man and domesticated animals.

In Kenya, a first local case of Aflatoxicosis poisoning was reported in the late 1970s in the former eastern province. However, the worst aflatoxin outbreak happened in 2004 in Kitui and Makueni districts of the then eastern province of Kenya. ${ }^{[4,5]}$ Ever since, the eastern region remains to be an aflatoxin prone area. ${ }^{[6]}$ By this time nobody knew what was happening until when samples collected from the affected patients to investigate for possible known causes of hepatitis returned negative results for known viral infections (Environ Health Perspect, 2005). Further evaluation, gave a similar clinical picture and resembles that seen in aflatoxin poisoning from symptomatic cases reported in Machakos in 1981. ${ }^{\text {[7] }}$ This was followed by maize sampling from the affected areas for analysis which confirmed the presence AFBl with as high as $4400 \mu \mathrm{g} / \mathrm{kg}$. This on average was far above the minimum required standard of $10 \mu \mathrm{g} / \mathrm{kg}$ of aflatoxin levels recommended for food meant for human consumption. [8-10] This outbreak was attributed to widespread aflatoxin contamination of maize grown locally characterized by poor drying, storage under damp conditions and exposure to humid conditions. ${ }^{[6]}$

Several preventive strategies are available with most of them focusing on proper pre and post-harvesting storage, adequate processing before consumption, of food cereals and many others. Aflatoxins contamination depends on various factors ranging from; how crops are planted, harvested, stored, and processed for human and animal consumption. However irrespective of having adequate measures to combat aflatoxins poisoning what we need to remember is that they are not destroyed by heating at the time of food preparation. The same is still applicable to manufactured products like peanut butter and other industrial processed products and their potency would still affect the consumer depending on the quantity of food available. ${ }^{[1-16]}$ The focus of this study was therefore to determine the prevalence rates and compliance to aflatoxin preventive measures among the residents of Makueni County, previously affected by Aflatoxicosis.

\section{METHODS}

\section{Study Area}

This study was purposefully carried out in Makueni County, which had the highest number of fatalities following Aflatoxin poisoning in 2004. The County is made up of five Sub-Counties namely; Mbooni, Kaiti, Kilome, Kibwezi West and Kibwezi East. The County has a total population of 987,653 communities (Census, 2019). Its annual rainfall ranges between 800-1200 mm. Majority of the County is arid with temperature ranging between $20^{\circ} \mathrm{C}$ to $24^{\circ} \mathrm{C}$. Farming in the area is largely for subsistence crops like maize, beans, peas, cassava sweet potatoes, millet, and sorghum. They also do fruit farming of watermelons, pawpaw, oranges, mangoes and lemons. Their main domesticated animals include cows, goats, sheep, and donkeys.

\section{Study Design}

This was a cross-sectional study and using primary information collected randomly from the patients attending Makueni County Referral Hospital through the collection of urine samples for laboratory analysis, 
interviews and hospital records for those undergoing treatment or have completed treatment and information on any death.

\section{Study Population, Inclusion and Exclusion Criteria Sample Size}

The sample size was 100 participants determined based on the incidence rate due to infected maize consumed at the time of the 2004 outbreak of aflatoxin in which Makueni County had the highest deaths. ${ }^{[17]}$

\section{Sampling Procedure}

Urine samples were collected by participants in clean containers at Makueni county referral hospital in the month of May 2020 . The samples were frozen at $-20^{\circ} \mathrm{C}$ until analysis.

\section{Analyzing Urine for the Presence of Aflatoxin}

The urine samples were collected in sterile urine containers and transported in a cool box to Bora Biotech Labs in Nairobi for aflatoxin Mldetection. Before the samples were analyzed, they were allowed to thaw at room temperature. Then $5 \mathrm{ml}$ of thawed urine from each participant was centrifuged at 4000 rpm for at least $10 \mathrm{~min}$. Skatron assay tubes were labeled with the participant's sample identification number. Then $950 \mathrm{ml}$ of distilled water were pipetted into skatron (SKATRON AS LIER, Norway. CAT. No 7071) tubes and $50 \mu \mathrm{l}$ of standards or supernatanturine was added into $950 \mu \mathrm{l}$ of distilled water in the skatron tubes and mixed by priming pipetting at least five times. $200 \mu \mathrm{l}$ of the assay buffer was added into the mixing well per plate and $100 \mu \mathrm{l}$ of the diluted standards (ranging from 0 to $40 \mathrm{ppt}$ ) and urine samples were added into the wells.

The contents of the mixing well were shaken using a micro-shaker (DYNATECH) for $2 \mathrm{~min}$. One hundred microliters of the mixture were transferred to the antibody-coated Reaction-Assay Plate (aflatoxin Ml assay for urine, Helica Biosystems Inc, 1527 W. Alton Santa Ana, California, USA). The samples were mixed by shaking for 1 min and incubated at $18-28^{\circ} \mathrm{C}$ in the dark for $1 \mathrm{~h}$. The plate was washed three times using phosphate-buffered saline-Tween-20 (0.05\%) using the well-wash (Thermo Scientific, Finland) machine with 3-min intervals between the washes. After drying, $100 \mu \mathrm{l}$ of the conjugate was added into each well, mixed gently by tapping, and incubated at room temperature for $15 \mathrm{~min}$ in the dark. The plate was then washed and $100 \mu \mathrm{l}$ of substrate reagent (tetramethylethidine) was added into each well, mixed gently by tapping, and incubated at room temperature for $15 \mathrm{~min}$ in the dark. The reactions were stopped by adding $100 \mu \mathrm{l}$ per well of stop solution and the optical density (OD) read at $450 \mathrm{~nm}$ within 15 min of stopping the reaction. The level in each sample was determined using the program from the kit manufacturer, which allowed calculations of the levels based on the absorbance readings.

\section{Ethical Consideration}

Ethical approval was obtained from the Kenyatta University's Ethical review committee. Other authorizations sought before the commencement of the study include informed written consent from the research participants, approval from NACOSTI and authorization from the hospital administration.

\section{Data Analysis}

Collected data were entered in a computer excel spreadsheets and statistically analyzed using SPSS Version 20.0. Exploration of the data was by numerical summaries together with the use of graphics. Social demography characteristics of the participants were presented in contingency tables as mean \pm standard deviation. The level of significance was accepted as $\mathrm{p}<$ 0.05 . The strength of association between variables was determined using chi-square test.

\section{RESULTS}

\section{Sociodemographic Characteristics of the Participants} Age distribution of studies of participants

The study participants, including both males and females, had an age range of between 15 and 91 years. On average the participants were between $41 \pm 18$ of age. Majority of the study participants were with a median age of 24 years old. Half of the selected participants were aged between 15 and 35 years $n=50$ $(47 \%)$ (Figure 1). A total of 106 study participants underwent an initial examination that included a medical history taking. Of the 106 screened study participants, all were to be of sound health and were nonsmokers. For the analyses conducted in the current study, no study participants were excluded. 


\section{FIGURE 1: Age distribution of the research participants}

\section{Frequency}

30

25

20

15

10

5

0
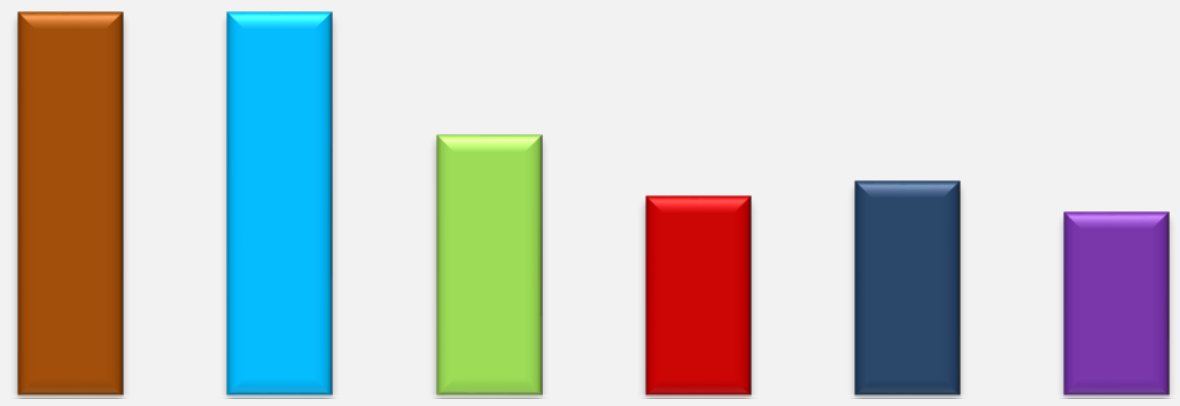

15-25 yrs. 26-35 yrs.

36-45

46-55 yrs. 56-65 yrs.

above 66

yrs.

$\square 15-25$ yrs. $\square 26-35 \mathrm{yrs} . \square 36-45 \square 46-55 \mathrm{yrs} . \square 56-65 \mathrm{yrs} . \square$ above $66 \mathrm{yrs}$.

\section{Gender distribution of studies of participants}

Figure 2 gives a representation of the gender distribution of study participants. Out of 106 study

participants, $\mathrm{n}=76(72 \%)$ were females and $\mathrm{n}=30$ $(28 \%)$ were males.

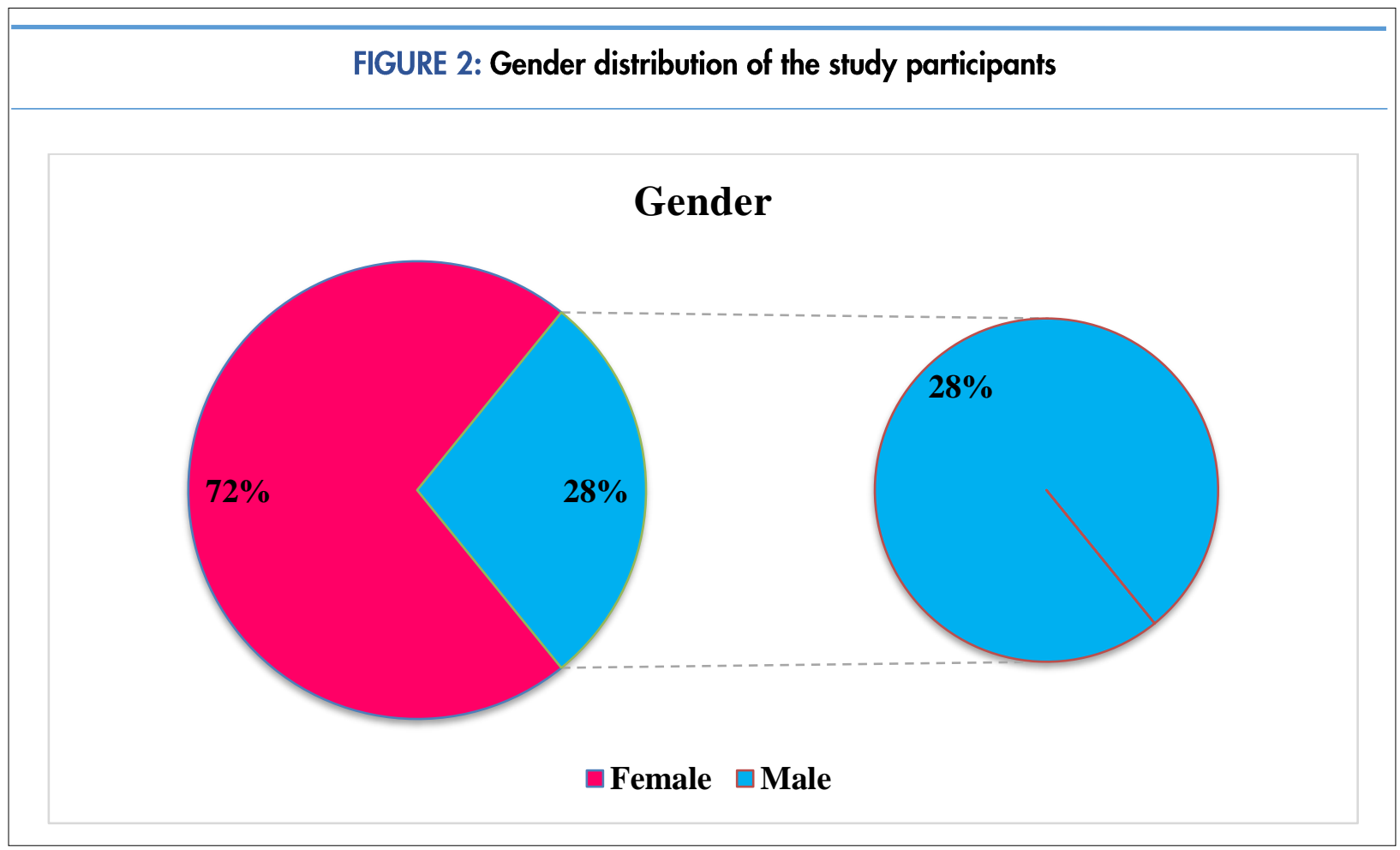




\section{The current prevalence rates of Aflatoxicosis}

The study had an aim of establishing whether there was a reduction in the prevalence rate in Makueni County and this after some intensive prevention and control strategies after the initial outbreak of 2004. To achieve this aim urine aflatoxin levels were used as a parameter to measure the exposure rates of resident of Makueni county. At the time of the study samples with AFMl concentration below $0.0 \mathrm{pg} / \mathrm{ml}$ were categorized as negative samples and those with detectable level above $1 \mathrm{pg} / \mathrm{ml}$ of AFMl through the extrapolation from the standard curve were categorized as positive samples. Of 106 urine samples analyzed during the study period, 105 had AFMl urine concentration levels of above $1 \mathrm{pg} / \mathrm{ml}$ which were categorized as a positive finding. Only one sample had an assay value reading of $0.0 \mathrm{pg} / \mathrm{ml}$ and this was categorized as a negative value. From those with positive AFM1, 39 had Aflatoxins value below $300 \mathrm{pg} / \mathrm{mL}$. The rest had a value greater than 300 $\mathrm{pg} / \mathrm{ml}$, where the majority fall. The positive 105 samples had urinary AFM1 concentration ranging from 25 to $2375 \mathrm{pg} / \mathrm{mL}$, with an average of $637.6 \pm 512.8 \mathrm{pg} / \mathrm{mL}$. The urinary levels of AFM1 were detected by enzyme-linked immunosorbent assay. AFM1 was detected in $99.1 \%$ of all urine samples at a range of 25 to $2375 \mathrm{pg} / \mathrm{mL}$ (Table 1). This gives a typical picture of what happens when aflatoxins are ingested in contaminated food and animal products. In the liver, the ingested aflatoxin (AFB 1 ) is converted to aflatoxin M1 (AFM1), a metabolite that we have used in our study as a biomarker of AFB 1 exposure, as it is excreted in the urine, and therefore suitable for our study. 


\section{TABLE 1. The urinary concentration of Aflatoxin in residents of Makueni County}

\begin{tabular}{|c|c|c|c|c|c|c|c|c|c|c|}
\hline \multirow[t]{2}{*}{ Characteristics } & \multicolumn{10}{|c|}{ The concentration of AFs in $\mathrm{pg} / \mathrm{ml}$} \\
\hline & $\begin{array}{l}\text { Below } \\
100\end{array}$ & $101-300$ & $301-500$ & $501-700$ & $701-900$ & $901-1100$ & $\begin{array}{l}1101- \\
1300\end{array}$ & $\begin{array}{l}1301- \\
1500\end{array}$ & $\begin{array}{l}1501- \\
1700 \\
\end{array}$ & $\begin{array}{l}\text { Above } \\
1701\end{array}$ \\
\hline \multicolumn{11}{|l|}{ Age groups } \\
\hline $15-25$ & $7(28.0 \%)$ & $\begin{array}{l}2 \\
(8.0 \%)\end{array}$ & $\begin{array}{l}1 \\
(4.0 \%)\end{array}$ & $3(12.0 \%)$ & $3(12.0 \%)$ & $4(16.0 \%)$ & $\begin{array}{l}1 \\
(4.0 \%)\end{array}$ & $\begin{array}{l}2 \\
(8.0 \%)\end{array}$ & $\begin{array}{l}0 \\
(0.0 \%)\end{array}$ & $\begin{array}{l}2 \\
(8.0 \%)\end{array}$ \\
\hline $26-35$ & 2 & $9(36.0 \%)$ & 1 & $\begin{array}{l}10 \\
(40.0 \%)\end{array}$ & $\begin{array}{l}0 \\
(0.0 \%)\end{array}$ & $\begin{array}{l}0 \\
(0.0 \%)\end{array}$ & 1 & $\begin{array}{l}2 \\
(8.0 \%)\end{array}$ & $\begin{array}{l}0 \\
(0.0 \%)\end{array}$ & $\begin{array}{l}0 \\
(0.0 \%)\end{array}$ \\
\hline $36-45$ & $2(11.8 \%)$ & $2(11.8 \%)$ & $3(17.6 \%)$ & $2(11.8 \%)$ & $\begin{array}{l}4 \\
(23.5 \%)\end{array}$ & $\begin{array}{l}1 \\
(5.9 \%)\end{array}$ & $1(5.9 \%)$ & $1(5.9 \%)$ & $0(0.0 \%)$ & $\begin{array}{l}1 \\
(5.9 \%)\end{array}$ \\
\hline $46-55$ & $4(30.8 \%)$ & $\begin{array}{l}1 \\
(7.7 \%)\end{array}$ & $\begin{array}{l}1 \\
(7.7 \%)\end{array}$ & $\begin{array}{l}1 \\
(7.7 \%)\end{array}$ & $(0.0 \%)$ & 3 & $\begin{array}{l}1 \\
(7.7 \%)\end{array}$ & $\begin{array}{l}1 \\
(7.7 \%)\end{array}$ & $\begin{array}{l}0 \\
(0.0 \%)\end{array}$ & $(7.7 \%)$ \\
\hline $56-65$ & $\begin{array}{l}2 \\
(14.3 \%)\end{array}$ & $2(14.3 \%)$ & 1 & $\begin{array}{l}0 \\
(0.0 \%)\end{array}$ & $\begin{array}{l}3 \\
(21.4 \%)\end{array}$ & 2 & $17.1 \%)$ & $2(14.3 \%)$ & $1(7.1 \%)$ & $\begin{array}{l}0 \\
(0.0 \%)\end{array}$ \\
\hline above 66 & $2(16.7 \%)$ & $4(33.3 \%)$ & $2(16.7 \%)$ & $\begin{array}{l}1 \\
(8.3 \%)\end{array}$ & $\begin{array}{l}2 \\
(16.7 \%)\end{array}$ & $\begin{array}{l}1 \\
(8.3 \%)\end{array}$ & $\begin{array}{l}0 \\
(0.0 \%)\end{array}$ & $\begin{array}{l}0 \\
(0.0 \%)\end{array}$ & $\begin{array}{l}0 \\
(0.0 \%)\end{array}$ & $\begin{array}{l}0 \\
(0.0 \%)\end{array}$ \\
\hline \multicolumn{11}{|l|}{ Gender } \\
\hline Male & $\begin{array}{l}7 \\
(23.3 \%)\end{array}$ & $3(10.0 \%)$ & $3(10.0 \%)$ & $6(20.0 \%)$ & 3 & $\begin{array}{l}3 \\
(10.0 \%)\end{array}$ & $\begin{array}{l}1 \\
(3.3 \%)\end{array}$ & $\begin{array}{l}2 \\
(6.7 \%)\end{array}$ & $\begin{array}{l}0 \\
(0.0 \%)\end{array}$ & 2 \\
\hline Female & $\begin{array}{l}12 \\
(15.8 \%)\end{array}$ & $\begin{array}{l}17 \\
(22.4 \%)\end{array}$ & $\begin{array}{l}6 \\
(7.9 \%)\end{array}$ & $\begin{array}{l}11 \\
(14.5 \%)\end{array}$ & $\begin{array}{l}9 \\
(11.8 \%)\end{array}$ & $\begin{array}{l}8 \\
(10.5 \%)\end{array}$ & $\begin{array}{l}4 \\
(5.3 \%)\end{array}$ & $\begin{array}{l}6 \\
(7.9 \%)\end{array}$ & $\begin{array}{l}1 \\
(1.3 \%)\end{array}$ & $\begin{array}{l}2 \\
(2.6 \%)\end{array}$ \\
\hline
\end{tabular}




\section{DISCUSSION}

Aflatoxins metabolites are common in groundnuts, cereals, and spices and herbs, which are widely used as the main food commodities for human and animal consumptions globally. [17-27] All food supplies are plant-related products, animal products such as meat and dairy products are in danger of being contaminated with aflatoxin. Animal products get tainted when such animals are on plant diet that is tainted with aflatoxin. The level of contamination in both cereal and animal products varies from country to country or even at a local level. For example, the Kenya National Bureau of Standards, a state organ with the mandate to ensure the safety of consumer products in the country found that 19 out of 53 samples of dairy products were tainted with AFM1, ranging from 3.5 to $100.5 \mathrm{ng} / \mathrm{L} .{ }^{[28-34]}$ The Kenyan population is among some of the African people who consume cereals products daily as this forms one of their staple food supply. ${ }^{[35]}$

\section{The current prevalence rates of Aflatoxicosis}

In our study, the prevalence rate was at $99.1 \%$ from the 106 urine samples analyzed. This prevalence of urinary AFM1 was relatively higher than the $79 \%$ and $83 \%$ reported by Kang'ethe et al $2017^{[36,37]}$ in their previous studies in children below the age of five years in Makueni and Nandi counties, respectively. The high prevalence found in the present study could be attributed to continuous exposure to aflatoxins tainted food even at the time of adulthood. These results were also similar to the $86 \%$ prevalence reported by Polychronaki et al. 2008 among children in Guinea ${ }^{\text {[38] }}$ The prevalence rate was also higher than those reported in other countries such as $30 \%$ in Egypt ${ }^{[38]}$, Sanchez et al. 2019 reported a $41.7 \%$ in Colombia children ${ }^{[39]}$, Ali et al also found a $40 \%$ prevalence rate among a rural population in Bangladesh [40] and Ayelign et al 2017 reported a prevalence rate of $17 \%$ from Ethiopian children. ${ }^{[41]}$ The presence of AFM1 in urine as seen in this study gives a picture of continuous exposure to aflatoxin-tainted food commodities in the entire lives of individuals from this County. This high number can be explained by the high level of aflatoxins contamination and continuous ingestion of AFB1 in food, which is eventually degraded to AFM1 by the liver and easily excreted by kidneys. Aflatoxins metabolized by the liver results into end products such as AFB 1-lysine adduct ${ }^{[42-44]}$, AFB 1-N7-guanine adduct [45], and urinary AFMl commonly found in urine. Aflatoxin contamination of animal products has been reported in various studies across the world. ${ }^{[46-57]}$ The first Aflatoxicosis case related to aflatoxin contamination was reported in turkeys and ducklings in the 1960s, where millions died as a result of consuming AFB1-tainted feeds. ${ }^{[58-60]}$

All these cases could be related to the higher consumption of aflatoxin-tainted staple food, an aspect that contributed to the largest outbreak of human Aflatoxicosis and food contamination in Makueni and subsequent attacks as reported by various studies from different regions of the country. ${ }^{[4}$, $7,10,36,48,61-85]$ The outbreaks reported as high as 8000 $\mu \mathrm{g} / \mathrm{kg}$ of aflatoxin contamination in maize in which 125 of people who consumed it never survived the poisoning. Most mycotoxins are stable at the time of food processing ${ }^{[17,86-90]}$ so it can even show up in food products such as peanut butter and many processed products. However, certain food preparation techniques can minimize the level of toxicity. [11]

\section{CONCLUSION}

The results from this study provided the current situation on aflatoxin exposure to the people of Makueni and at the same time offered feedback that served to monitor what is happening and if the initiated preventive strategies for Aflatoxicosis are working. From what is evident from our study, the findings suggest higher aflatoxin concentration among the resident of Makueni County, where there is an urgent need to mitigate the long-term effect of this high exposure. Therefore, the study is recommending to the concerned ministry to have a broader focus on the extent of aflatoxin food contamination from this region plus other regions across the country. This will be so important to protect vulnerable communities and the general population of the country as a whole from this carcinogenic exposure. Some of the recommendations we propose include; regular training on good agricultural practices, routine food sampling for aflatoxin levels, the introduction of a modern method to control aflatoxin food contamination and more research to be done to understand the impact of this high exposure to the health of the vulnerable population.

Acknowledgements: I extend my gratitude to the Biotech Labs Nairobi for allowing me to carry out the laboratory tests there as well as Makueni Referral Hospital Laboratory for their support in the sample collection and to my wife Faith and our children, Taji and Tiara for their unequivocal encouragement to make this work possible. 


\section{Financial Support}

\section{No financial support offered}

\section{Conflict of Interest}

The authors declare no conflict of interest related to this study

\section{REFERENCES}

1. Bordini J.G., Ono M.A, Hirozawa MT, Garcia GT, Vizoni E, Ono EYS. Safety of Corn and Corn-Based Products Intended for Human Consumption Concerning Fumonisins from a Brazilian Processing Plant. Toxins (Basel), 2019.11(1):33.

2. Bryla M, Waśkiewicz A, Ksieniewicz-Woźniak E, Szymczyk K, Jedrzejczak R. Modified Fusarium Mycotoxins in Cereals and Their Products-Metabolism, Occurrence, and Toxicity: An Updated Review. Molecules, 2018. 23(4):963.

3. Daniel JH, Lewis LW, Redwood YA, et al. Comprehensive assessment of maize aflatoxin levels in Eastern Kenya, 2005-2007. Environ Health Perspect, 2011 . 119(12):1794-

4. Probst C, Njapau H, Cotty PJ. Outbreak of an acute aflatoxicosis in Kenya in 2004: identification of the causal agent. Appl Environ Microbiol, 2007. 73(8): p. 2762-4.

5. Yard EE, Daniel JH, Lewis LS, et al. Human aflatoxin exposure in Kenya, 2007: a cross-sectional study. Food Addit Contam Part A Chem Anal Control Expo Risk Assess, 2013. 30(7):1322-31.

6. Azziz-Baumgartner E, Lindblade K, Gieseker K, et al. Casecontrol study of an acute aflatoxicosis outbreak, Kenya, 2004. Environ Health Perspect, 2005. 113(12):1779-83.

7. Muture BN and Ogana G. Aflatoxin levels in maize and maize products during the 2004 food poisoning outbreak in Eastern Province of Kenya. East Afr Med J, 2005. 82(6):275-9.

8. Abdallah MF, Girgin G, Baydar T. Mycotoxin Detection in Maize, Commercial Feed, and Raw Dairy Milk Samples from Assiut City, Egypt. Vet Sci, 2019. 6(2).

9. Habibipour, R., P.R. Tamandegani, and A. Farmany, Monitoring of aflatoxin G1, B1, G2, and B2 occurrence in some samples of walnut. Environ Monit Assess, 2016 188(12):669.

10. Mwihia JT, Straetmans M, Ibrshim A, et al. Aflatoxin levels in locally grown maize from Makueni District, Kenya. East Afr Med J, 2008. 85(7):311-7.

11. Xie $H$, Wang $X$, Zhang $L$ et al. Monitoring Metabolite Production of Aflatoxin Biosynthesis by Orbitrap Fusion Mass Spectrometry and a D-Optimal Mixture Design Method. Anal Chem, 2018. 90(24):14331-14338.

12. Watson S, Chen G, Sylla A, Routledge MN, Gong YY. Dietary exposure to aflatoxin and micronutrient status among young children from Guinea. Mol Nutr Food Res 2016. 60(3):511-8

13. Akhtar S, Shahzad MA, Yoo SH, Ismail A, et al. Determination of Aflatoxin M1 and Heavy Metals in Infant Formula Milk Brands Available in Pakistani Markets. Korean J Food Sci Anim Resour, 2017. 37(1):79-86.

14. Di Gregorio MC, Jager AV, Costa AA, et al. Determination of Aflatoxin B 1-Lysine in Pig Serum and Plasma by Liquid Chromatography-Tandem Mass Spectrometry. J Anal Toxicol, 2017. 41(3):236-241.

15. Mitchell NJ, Hsu HH, Chandyo RK, Shrestha B, et al. Aflatoxin exposure during the first 36 months of life was not associated with impaired growth in Nepalese children: An extension of the MAL-ED study. PLoS One, 2017. 12(2): p. e0172124.

16. Gilbert Sandoval I, Wesseling S, and Rietjens IMCM.Aflatoxin B1 in nixtamalized maize in Mexico; occurrence and accompanying risk assessment. Toxicol Rep, 2019. 6:1135-1142.

17. Wagacha JM Muthomi JW, Mycotoxin problem in Africa: current status, implications to food safety and health and
18.

19.

possible management strategies. Int $\mathrm{J}$ Food Microbiol, 2008. 124(1):1-12.

Udomkun P, Mutegi C, Wossen T, et al. Occurrence of aflatoxin in agricultural produce from local markets in Burundi and Eastern Democratic Republic of Congo. Food Sci Nutr, 2018. 6(8):2227-2238.

Mohammedi-Ameur S, Dahmane M, Brera C, Kardjadj M, Ben-Mahdi MH. Occurrence and seasonal variation of aflatoxin $\mathrm{Ml}$ in raw cow milk collected from different regions of Algeria. Vet World, 2020. 13(3):433-439.

20. Pesavento G, Ostuni M, Calonico C, Rossi S, Capei R, Lo NostroA. Mycotic and aflatoxin contamination in Myristica fragrans seeds (nutmeg) and Capsicum annum (chilli), packaged in Italy and commercialized worldwide. J Prev Med Hyg, 2016. 57(2):E102-9.

21. Falade TDO, Chrysanthopoulos PK, Hodson MP, et al. Metabolites Identified during Varied Doses of Aspergillus Species in Zea mays Grains, and Their Correlation with Aflatoxin Levels. Toxins (Basel), 2018. 10(5)

22. Lauer JM, Duggan CP, Ausman LM, et al. Maternal aflatoxin exposure during pregnancy and adverse birth outcomes in Uganda. Matern Child Nutr, 2019. 15(2): p. el2701.

23. Al-Zoreky NS and Saleh FA., Limited survey on aflatoxin contamination in rice. Saudi J Biol Sci, 2019. 26(2):225231.

24. Zyoud SH. Global scientific trends on aflatoxin research during 1998-2017: a bibliometric and visualized study. J Occup Med Toxicol, 2019. 14:27.

25. Chauhan NM, Washe AP and Minota T. Fungal infection and aflatoxin contamination in maize collected from Gedeo zone, Ethiopia. Springerplus, 2016. 5(1):753.

26. Khlangwiset $\mathrm{P}$ and Wu F. Costs and efficacy of public health interventions to reduce aflatoxin-induced human disease. Food Addit Contam Part A Chem Anal Control Expo Risk Assess, 2010. 27(7):998-1014.

27. Rajasekaran K, Sayler RJ, Sickler CM, Majum dar R, Jaynes JM, Cary JW. Control of Aspergillus flavus growth and aflatoxin production in transgenic maize kernels expressing a tachyplesin-derived synthetic peptide, AGM182. Plant Sci, 2018. 270:150-156.

28. Ismaiel AA, Tharwat NA, Sayed MA, Gameh SA. Two-year survey on the seasonal incidence of aflatoxin M1 in traditional dairy products in Egypt. J Food Sci Technol, 2020. 57(6):2182-2189.

29. Di Giovanni S, Zambrini V, Varriale A, D'Auria S. Sweet Sensor for the Detection of Aflatoxin Ml in Whole Milk. ACS Omega, 2019. 4(7):12803-12807.

30. Ahlberg S, Grace D, Kiarie G, Kirino Y, Lindahl J. A Risk Assessment of Aflatoxin Ml Exposure in Low and MidIncome Dairy Consumers in Kenya. Toxins (Basel), 2018. 10(9).348.

31. Campone L, Piccinelli AL, Celano R, Pagano I, Russo M, Rastrelli. Rapid and automated analysis of aflatoxin Ml in milk and dairy products by online solid phase extraction coupled to ultra-high-pressure-liquid-chromatography tandem mass spectrometry. J Chromatogr A, 2016. 1428:212-9.

32. Kuboka MM, Imungi JK, Njue L, Mutua F, Grace D, Lindahl JF. Occurrence of aflatoxin M1 in raw milk traded in peri-urban Nairobi, and the effect of boiling and fermentation. Infect Ecol Epidemiol, 2019. 9(1):1625703.

33. Li S, Min L, Wang G, Li D, Zheng N, Wang J. Occurrence of Aflatoxin M1 in Raw Milk from Manufacturers of Infant Milk Powder in China. Int J Environ Res Public Health, 2018. 15(5):879.

34. Venancio RL, Ludovico A, de Santana EHW, de Toledo EA, de Almeida Rego FC, Dos Santos JS. Occurrence and seasonality of aflatoxin M1 in milk in two different climate zones. J Sci Food Agric, 2019. 99(6):3203-3206.

35. Seetha A. Monyo ES, Tsusaka TW, et al. Aflatoxin-lysine adducts in blood serum of the Malawian rural population and aflatoxin contamination in foods (groundnuts, maize) in the corresponding areas. Mycotoxin Res, 2018. 34(3):195-204.

36. Kang'ethe EK, Gawiri M, Sirma AJ. et at. Exposure of Kenyan population to aflatoxins in foods with special reference to Nandi and Makueni counties. Food Quality and Safety, 2017. 1(2). 
37. Kiarie GM, Dominguez-Salas P, Kang'ethe SK, Grace D, J Lindahl J. Aflatoxin exposure among young children in urban low-income areas of nairobi and association with child growth. ajfand, 2016. 16(3).

38. Polychronaki N, Wild CP, Mykkänen $\mathrm{H}$, et al. Urinary biomarkers of aflatoxin exposure in young children from Egypt and Guinea. Food Chem Toxicol, 2008. 46(2):51926.

39. Sanchez EM. and Diaz GJ. Frequency and levels of aflatoxin $\mathrm{Ml}$ in urine of children in Bogota, Colombia. Mycotoxin Res, 2019.35(3):271-278.40. Ali N, Hossain K, Blaszkewicz M, et al. Occurrence of aflatoxin Ml in urines from rural and urban adult cohorts in Bangladesh. Arch Toxicol, 2016. 90(7):1749-55.

41. Ayelign A, Woldegiorgis AZ, Adish A, De Boevre M Heyndrickx E, De Saeger S, et al. Assessment of aflatoxin exposure among young children in Ethiopia using urinary biomarkers. Food Addit Contam Part A Chem Anal Control Expo Risk Assess, 2017. 34(9):1606-1616.

42. Adepo JA, Manda P, Ngbé JV, Diakité A, Tigori Sangaré B, Dano SD. Study of aflatoxicosis reduction: effect of Alchornea cordifolia on biomarkers in an aflatoxin B1 exposed rats. Drug Chem Toxicol, 2019. 42(3):243-251.

43. Leroy JL, Wang JS, Jones K. Serum aflatoxin B(1)-lysine adduct level in adult women from Eastern Province in Kenya depends on household socio-economic status: A cross sectional study. Soc Sci Med, 2015. 146:104-10.

44. Mupunga I, Izaaks CD, Shai LJ, Katerere DR, et al. Aflatoxin biomarkers in hair may facilitate long-term exposure studies. J Appl Toxicol, 2017. 37(4):395-399.

45. Taguchi K, Takaku M, Egner PA, et al. Generation of a New Model Rat: Nrf2 Knockout Rats Are Sensitive to Aflatoxin B1 Toxicity. Toxicol Sci, 2016. 152(1):40-52.

46. Eker FY, Muratoglu K, and Eser AG. Detection of aflatoxin M1 in milk and milk products in Turkey. Environ Monit Assess, 2019. 191(8):523

47. Herrera M, Herrera A, AriñoA. Aflatoxins in food and feed: Contamination exposure, toxicology and control, in Aflatoxins: Food Sources, Occurrence and Toxicological Effects. 2014.

48. Lindahl JF, Kagera IN, Grace D. Aflatoxin M1 levels in different marketed milk products in Nairobi, Kenya. Mycotoxin Res, 2018. 34(4):289-295

49. Santos JS, França VR, Katto S, Santana EH. Aflatoxin M1 in pasteurized, UHT milk and milk powder commercialized in Londrina, Brazil and estimation of exposure. Arch Latinoam Nutr, 2015.65(3):181-5.

50. Miocinovic J, Keskic T, Miloradovic Z, Kos A, Tomasevic I, Pudja P. The aflatoxin M1 crisis in the Serbian dairy sector: the year after. Food Addit Contam Part B Surveill, 2017. $10(1): 1-4$.

51. Sharifzadeh A Ghasemi-Dehkordi P, Foroughi $M$ Mardanpour-Shahrekordi E, Ramazi S. Aflatoxin M1 Contamination Levels in Cheeses Sold in Isfahan Province Iran. Osong Public Health Res Perspect, 2017. 8(4):260263.

52. Ismail A, Gonçalves BL, de Neeff DV, et al. Aflatoxin in foodstuffs: Occurrence and recent advances in decontamination. Food Res Int, 2018. 113:74-85

53. American Society of Agronomy. and Soil Science Society of America., Aflatoxin control : safeguarding animal feed with calcium smectite. 2013, Madison, WI: American Society of Agronomy and Soil Science Society of America. viii, 67 pages.

54. Qi N, Yu H, Yang C, Gong X, Liu Y, Zhu Y. Aflatoxin B1 in peanut oil from Western Guangdong, China, during 20162017. Food Addit Contam Part B Surveill, 2019. 12(1):4551.

55. Mongkon W, Sugita-Konishi Y, Chaisri W, Suriyasathaporn W. Aflatoxin B l Contamination of Dairy Feeds after Storage in Farm Practice in Tropical Environmen. Biocontrol Sci, 2017. 22(1):41-45.

56. Battilani P, Toscano P, Van der Fels-Klerx HJ, et al. Aflatoxin B1 contamination in maize in Europe increases due to climate change. Sci Rep, 2016. 6:24328.

57. Sineque AR, Macuamule CL, and Dos Anjos FR. Aflatoxin B 1 Contamination in Chicken Livers and Gizzards from Industrial and Small Abattoirs, Measured by ELISA Technique in Maputo, Mozambique. Int J Environ Res Public Health, 2017. 14(9):951.
58. Reed KM, Mendoza KM, Coulombe RA Jr. Differential Transcriptome Responses to Aflatoxin $\mathrm{B}(1)$ in the Cecal Tonsil of Susceptible and Resistant Turkeys. Toxins (Basel), 2019. 11(1):55.

59. Reed KM, Mendoza KM, Coulombe RA Jr. Altered Gene Response to Aflatoxin B 1 in the Spleens of Susceptible and Resistant Turkeys. Toxins (Basel), 2019. 11(5):242.

60. Dhakal A and Sbar E. Aflatoxin Toxicity, in StatPearls internet. 2020: Treasure Island (FL). StatPearls Publishing; 2021 Jan. PMID: 32491713

61. Okoth S, Nyongesa B, Ayugi V, Kang'ethe E, Korhonen H, Joutsjoki V. Toxigenic potential of Aspergillus species occurring on maize kernels from two agro-ecological zones in Kenya. Toxins (Basel), 2012. 4(11):991-1007.

62. Kagera I, Kahenya P, Mutua F, et al. Status of aflatoxin contamination in cow milk produced in smallholder dairy farms in urban and peri-urban areas of Nairobi County: a case study of Kasarani sub county, Kenya. Infect Ecol Epidemiol, 2019. 9(1):1547095.

63. Sirma, AJ., Sources and levels of human exposure to aflatoxins in Nandi county, Kenya. Thesis, 2013.

64. Leroy JL, Wang JS, Jones K. Serum aflatoxin B-lysine adduct level in adult women from Eastern Province in Kenya depends on household socio-economic status: A cross sectional study. Soc Sci Med, 2015. 146:104-10.

65. Keter L, Too R, Mwikwabe N, et al. Risk of Fungi Associated with Aflatoxin and Fumonisin in Medicinal Herbal Products in the Kenyan Market. ScientificWorldJournal, 2017. 2017:1892972.

66. Maiyoh GK Tuei VC. Rising Cancer Incidence and Role of the Evolving Diet in Kenya. Nutr Cancer, 2019. 71(4):531546.

67. Mutegi CK, Cotty PJ, Bandyopadhyay R. Prevalence and mitigation of aflatoxins in Kenya (1960-to date). World Mycotoxin Journal, 2018. 11(3):341-357.

68. Centers for Disease, C. and Prevention, Outbreak of aflatoxin poisoning--eastern and central provinces, Kenya, January-July 2004. MMWR Morb Mortal Wkly Rep, 2004. $53(34): 790-3$.

69. Hoffmann V, Jones $\mathrm{K}$, Leroy J, Mitigating aflatoxin exposure to improve child growth in Eastern Kenya: study protocol for a randomized controlled trial. Trials, 2015. 16:552.

70. Nadhem Mtimet M., Baker D, Lindahl J, Hartmann M, Grace D. Kenyan Awareness of Aflatoxin: An Analysis of Processed Milk Consumers. in ICEA. 2015. Italy.

71. Njeru NK, Midega CAO, Muthomi JW, Wagacha JM, Khan ZR. Influence of socio-economic and agronomic factors on aflatoxin and fumonisin contamination of maize in western Kenya. Food Sci Nutr, 2019. 7(7):2291-2301.

72. Ndwiga J, Marechera G. Farmer perceptions of aflatoxin management strategies in lower Eastern Kenya. Journal of Agricultural Extension and Rural Contamination, 2014. 6 (12):382-392,

73. Obade MI, Andang'o P, Obonyo C, Lusweti F. Exposure of children 4 to 6 months of age to aflatoxin in Kisumu County, Kenya. ajfand, 2015. 15(2):9949-9963.

74. Githang'a D, Wangia RN, Mureithi MW, et al. The effects of aflatoxin exposure on Hepatitis B-vaccine induced immunity in Kenyan children. Curr Probl Pediatr Adolesc Health Care, 2019. 49(5):117-130.

75. Njoroge SM, Matumba L, Kanenga K, et al. A Case for Regular Aflatoxin Monitoring in Peanut Butter in SubSaharan Africa: Lessons from a 3-Year Survey in Zambia. J Food Prot, 2016. 79(5):795-800.

76. Mutiga SK, Hoffmann V, Harvey JW, Milgroom MG, Nelson RJ. Assessment of Aflatoxin and Fumonisin Contamination of Maize in Western Kenya. Phytopathology, 2015. 105(9):1250-61.

77. Mbuge DO, Negrini R, Nyakundi LO, et al. Application of superabsorbent polymers (SAP) as desiccants to dry maize and reduce aflatoxin contamination. J Food Sci Technol, 2016. 53(8):3157-3165.

78. Herrman TJ, Hoffmann V, Muiruri A, McCORMICK C. Aflatoxin Proficiency Testing and Control in Kenya. J Food Prot, 2020. 83(1):142-146.

79. Nabwire WR, Ombaka J, Dick CP, et al. Aflatoxin in household maize for human consumption in Kenya, East Africa. Food Addit Contam Part B Surveill, 2020. 13(1):45-51. 
80. Gong YY, Wilson S, Mwatha JK, et al. Aflatoxin exposure may contribute to chronic hepatomegaly in Kenyan schoo children. Environ Health Perspect, 2012. 120(6):893-6.

81. Wangia RN, Githanga DP, Wang JS, Anzala OA. Aflatoxin exposure in children age 6-12 years: a study protocol of a randomized comparative cross-sectional study in Kenya, East Africa. Pilot Feasibility Stud, 2019. 5:141

82. Sirma AJ, Makita K, Grace D, Senerwa D, Lindahl JF., Aflatoxin Exposure from Milk in Rural Kenya and the Contribution to the Risk of Liver Cancer. Toxins (Basel), 2019. $11(8): 469$.

83. Lewis L, Onsongo $M$, Njapau H et al. Aflatoxin contamination of commercial maize products during an outbreak of acute aflatoxicosis in eastern and central Kenya. Environ Health Perspect, 2005. 113(12):1763-7.

84. Musundire R, Osuga IM, Cheseto X, Irungu J, Torto B. Aflatoxin Contamination Detected in Nutrient and AntiOxidant Rich Edible Stink Bug Stored in Recycled Grain Containers. PLoS One, 2016. 11(1):e0145914.

85. Kang'ethe EK, Lang'a KA. Aflatoxin B1 and M1 contamination of animal feeds and milk from urban centers in Kenya. Afr Health Sci. 2009; 9(4):218-26..

86. Zhang C, Selvaraj JN, Yang Q, Liu Y. A Survey of Aflatoxin-Producing Aspergillus sp. from Peanut Field Soils in Four Agroecological Zones of China. Toxins (Basel), 2017. 9(1):40.

87. Bullerman LB, Bianchini A. Stability of mycotoxins during food processing. Int J Food Microbiol, 2007. 119(1-2):1406.

88. Mirza Alizadeh A, Jazaeri S, Shemshadi B, et al. A review on inactivation methods of Toxoplasma gondii in foods. Pathog Glob Health, 2018. 112(6):306-319.

89. Pallares N, Carballo D, Ferrer E, Fernández-Franzón M, Berrada H. Mycotoxin Dietary Exposure Assessment through Fruit Juices Consumption in Children and Adult Population. Toxins (Basel), 2019. 11(12):684.

90. Pinotti L, Ottoboni M, Giromini C, Dell'Orto V, Cheli F. Mycotoxin Contamination in the EU Feed Supply Chain: A Focus on Cereal Byproducts. Toxins (Basel), 2016. 8(2):45.

91. Zhao Q, Qiu Y, Wang X, et al. Inhibitory Effects of Eurotium cristatum on Growth and Aflatoxin B 1 Biosynthesis in Aspergillus flavus. Front Microbiol, 2020. 11:921.

Peer Reviewed

Competing Interests: None declared.

Received: 7/8/2020; Accepted: 2/22/2021

Cite this article as: Buuri M, Gicheru M, Mutiso $\mathrm{J}$ and Mulakoli F. Survey of Urinary Aflatoxin Levels Among Residents of Makueni County, Kenya: A Follow-Up Study. E Afr Sci. 2021;3(1):67-76. http://doi.org/10.24248/EASci-D-20-00013

(C) Buuri et al. This is an open-access article distributed under the terms of the Creative Commons Attribution License, which permits unrestricted use, distribution, and reproduction in any medium, provided the original author and source are properly cited. To view a copy of the license, visit http://creativecommons.org/licens- es/by/4.0/. When linking to this article, please use the following permanent link: http://doi.org/10.24248/EASci-D-20-00013 